\title{
The Excavation of Pulemelei Site 2002-2004
}

\author{
HELENE MARTINSSON-WALLIN, PAUL WALLIN and GEOFFREY CLARK
}

\begin{abstract}
This paper describes the results of archaeological excavations in the Pulemelei mound on Savai' $i$, thought to be the largest freestanding stone structure in Polynesia, in 2002-4. These excavations comprise the first large-scale archaeological investigation of a monumental complex in Samoa. We examine the chronology and function of the large mound and other structures.
\end{abstract}

Prior to our investigations, the Pulemelei mound and other prehistoric features in the Letolo plantation had been surveyed, and used to interpret Samoan demography and settlement patterns in the late prehistoric period (Jennings et al. 1982; Scott 1969; Green 2002; Asaua 2005). The extensive survey of prehistoric remains at Letolo plantation by Gregory Jackmond in 1977-1978 recorded more than 3000 features, including 1059 stone platforms, roads, along with stone fences and walkways, earth ovens and refuse piles (Jennings et al. 1982: 87-93, see Wallin, MartinssonWallin and Clark, this publication, Figure 1). The Pulemelei mound in traditional history had been suggested to be a tia seu lupe (pigeon snaring mound) and/or the residence of the chief Lilomaiava Nailevaiiliili, who is suggested by Krämer (1994:243) to have lived 25 generations ago (ca. 16501680AD).

Previous researchers have noted: "four stone seats each with a conch shell" on top of the Pulemelei mound (Asaua 2005:82), and Scott (1969:82) reported the: “original informants suggestion that these [stone cairns] were receptacles or pedestals for large shell trumpets (foafoa)". A local tradition records that the mound was the residence of gods and spirits (atua, aitu), who were called back to the mound each night by the sound of a shell trumpet (Pulenu'u Toluono Pene, Vailoa village, pers. comm. 2006). A fragmentary shell trumpet (Cassis shell) was found beneath stones on the upper platform during cleaning of the mound in 1965 (Figure 1). A spire of Triton shell was also found on the smaller North mound (Scott 1969:86). During Scott's mapping (1969:80) ten stone cairns were found on top of the Pulemelei mound, but when the mound was re-mapped by us in 2002 about 40 cairns were recorded. The low cairns were removed during geophysical survey of the mound in 2004, but soon afterwards several cairns were set up. Workers from the local village who assisted in our investigations also brought shell trumpets to the Pulemelei mound.

Prior to our initial investigations in 2002 , there was limited archaeological knowledge about the Pulemelei mound, particularly its age, function, and relationship with adjacent prehistoric structures. Our project also focused on understanding the social context out of which a mound building tradition emerged, and the cultural connections among the prehistoric societies in Fiji-West Polynesia. To investigate the origin and development of large mounds in Samoa archaeological excavation, remote sensing and detailed mapping were made at the Pulemelei mound during three field seasons from 2002 to 2004 .

The investigations had the following aims:

1. Determine the chronology and construction sequence of the Pulemelei mound and adjacent structures by archaeological investigation.

2. Examine the development and meaning of monumental architecture at the Letolo plantation, and contrast Samoan monuments with those from other parts of West Polynesia.

3. Provide archaeological fieldwork and cultural heritage training for Samoan and overseas students, particularly the management of monumental sites impacted by tourism.

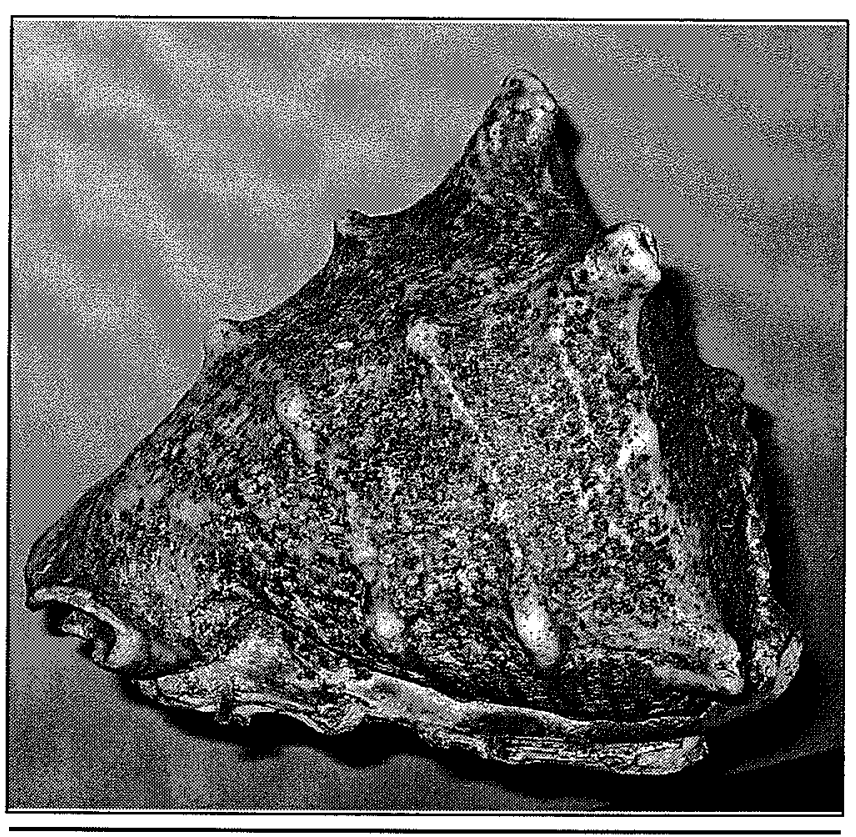

Figure 1. Shell trumpet (Cassis), found among stone rubble on the top of mound in the 60s. Auckland Museum. 
In this paper we focus on the first of these aims by presenting and discussing basic information about the archaeological investigations made at the Pulemelei site.

\section{Mound building}

The trend toward mound building in Samoa is apparent among other islands in West Polynesia during 1100 1700AD (Davidson 1979: 95; Green 2002). Contact and interaction between islands in West Polynesia is suggested by prehistoric material remains, and is evident in ethnohistorical accounts and traditional history (Clark 2002; Barns and Hunt 2005). However, the material expression is not homogeneous and differences among the late prehistoric landscapes of West Polynesia reflect the contingent cultural and environmental context on each island, and the specific influence of external interaction among island groups (see Clark and Martinsson-Wallin, this publication).

In Samoa, large house mounds of stone and earth are found on Savai'i and 'Upolu, but are rare or absent in American Samoa (Buist 1969:39; Davidson 1974:225-7; Clark 1996:452). Results of archaeological excavation and examination of traditional history suggest that large mounds - like those at Vailele on 'Upolu - had a residential function, and may have been constructed as early as $1100 \mathrm{AD}$, with continued use until ca. 1800AD (Green and Davidson 1974:219). It is also possible that Samoan mound building was influenced by intermarriage and war with Tonga (Kirch 1984:238-42). Jennings et al. (1982:92) suggest that the Pulemelei mound was built in the 17th century, as large mounds investigated at Mt Olo were likely to date to this period. Traditional records indicate that large mounds could have several functions including pigeon snaring, house foundations and ceremonial use (Scott 1969:87-90; Tamasese 2003, 2004). It has also been suggested that large Samoan mounds might be chiefly burial structures similar to the Tongan langi, but Davidson (1974:229-30) concluded that burials mainly occurred in shallow pits under, or, close to house foundations, and the raised mounds were residential units for high chiefs or were foundations for religious structures.

The Letolo site survey of prehistoric structures made by Jackmond (1977-78) has been used previously to analyse the distribution of prehistoric remains, particularly stone mounds, in order to reconstruct the Samoan settlement pattern. Results showed that settlement at Letolo was similar to that reported at Mt Olo on 'Upolu and Sa'papaili on Savai'i, although being slightly larger in extent. According to Jennings et al. (1982:87-92) the Letolo settlement consisted of five village 'wards' (pitonu'u), each of which comprised a cluster of two-to-five large platforms near a primary walkway and 50-75 household units enclosed by walkways and fences.

\section{Site setting}

At Letolo plantation in Palauli district the large stepped mound known as Pulemelei is situated about $1.5 \mathrm{~km}$ inland from the coast at ca.100 $\mathrm{m}$ above sea level (Figure 2). It has the base dimensions of ca. $65 \mathrm{~m}$ by $60 \mathrm{~m}$ and a maximum above ground height of ca. $12 \mathrm{~m}$. The plantation extends from the coast ca. $2.5 \mathrm{~km}$ inland to ca. $250 \mathrm{~m}$ above sea level (asl) on the south coast of Savai' $i$, and is bounded to the east by the Faleata River and on the west by the Seugagogo River.

The Letolo plantation is owned by the Nelson extended family, and in the past has been a copra plantation. The land is currently used for cattle grazing, but there are plans to develop the area for tourism in the future. According to Vailoa village the freehold plantation land is considered to be village land, and there have been several disputes between the plantation owners and the matai of Vailoa over

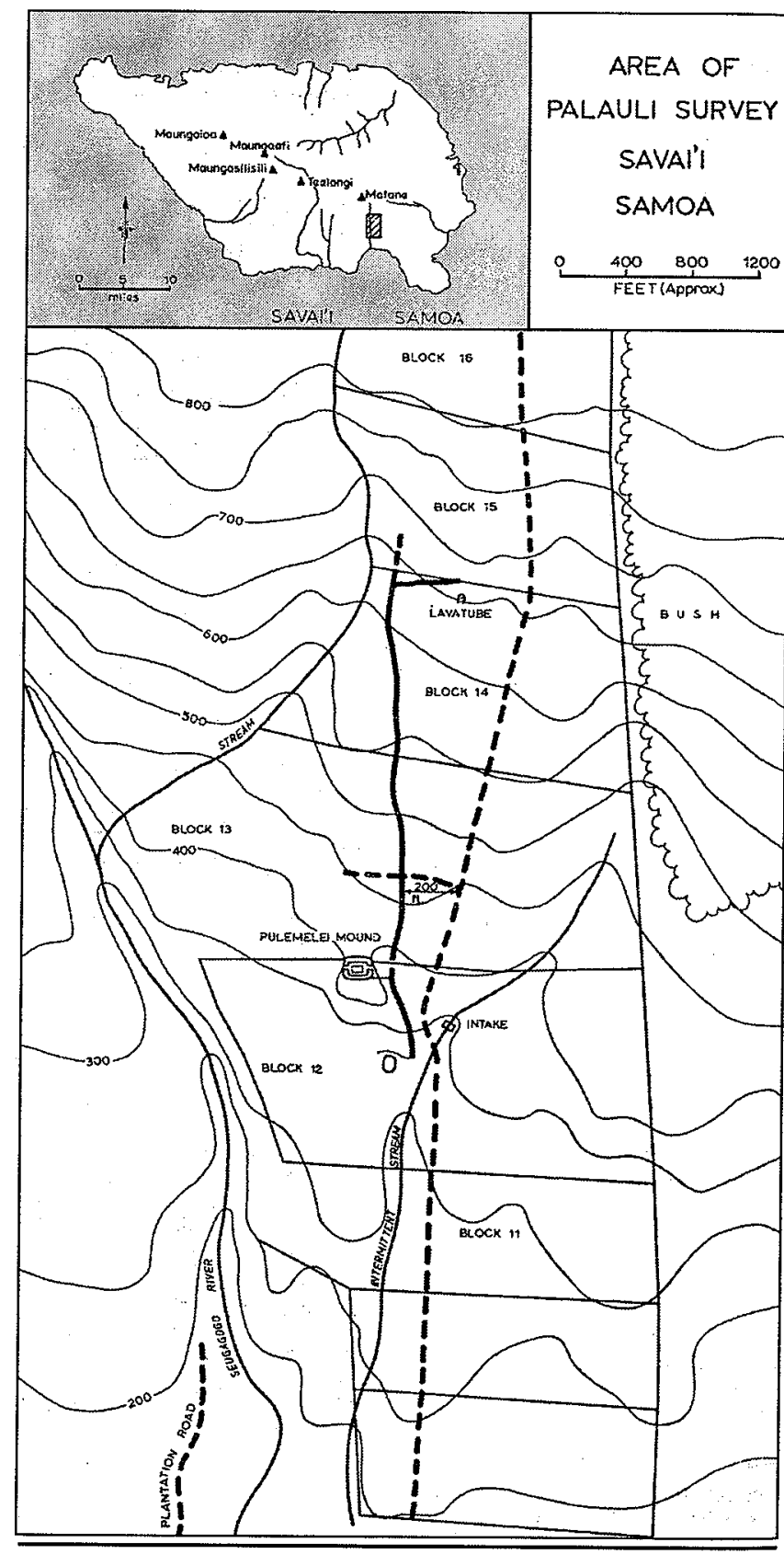

Figure 2. Letolo plantation and location of Pulemelei mound. 
the years. Ownership of the Letolo plantation is the subject of a current court case. Since plantation activities ceased in the 1980s a thick growth of secondary tropical vegetation has covered most of the plantation, but the Pulemelei mound and the Afu Aau (Olemoe) waterfall on the property are two of the main tourist attractions on Savai'i, and these are cleared and managed periodically.

\section{Archaeological investigations 2002-2004}

The archaeological investigation of the Pulemelei mound involved collaboration between academics (Helene Martinsson-Wallin, Paul Wallin, Kon-Tiki Museum Research Institute and Geoffrey Clark, Australian National University) and Samoan land owners represented by the board of the Nelson Corporation. Fieldwork was carried out during September 13-October 10 2002, July 17-August 15 2003, and June 5-25 2004. Preliminary results from the excavations have been presented in several reports and papers (Wallin et al. 2002; Martinsson-Wallin 2003, 2005; Martinsson-Wallin et al. 2003, 2005). Additional excavation carried out at Letolo in March 2006 is reported elsewhere (Martinsson-Wallin et al. 2006).

The 2002 field season concentrated on clearing and mapping the Pulemelei mound, which was covered in a thick growth of tree and scrub vegetation, with several small test excavations made around the base of the mound. An area of ca. $20,000 \mathrm{~m}^{2}$ was cleared of vegetation during investigations (Figure 3 a, b, c). In Scott's (1969: 81) initial description of the Pulemelei mound made in 1965, he noted that its shape was essentially unaltered, with only a minor

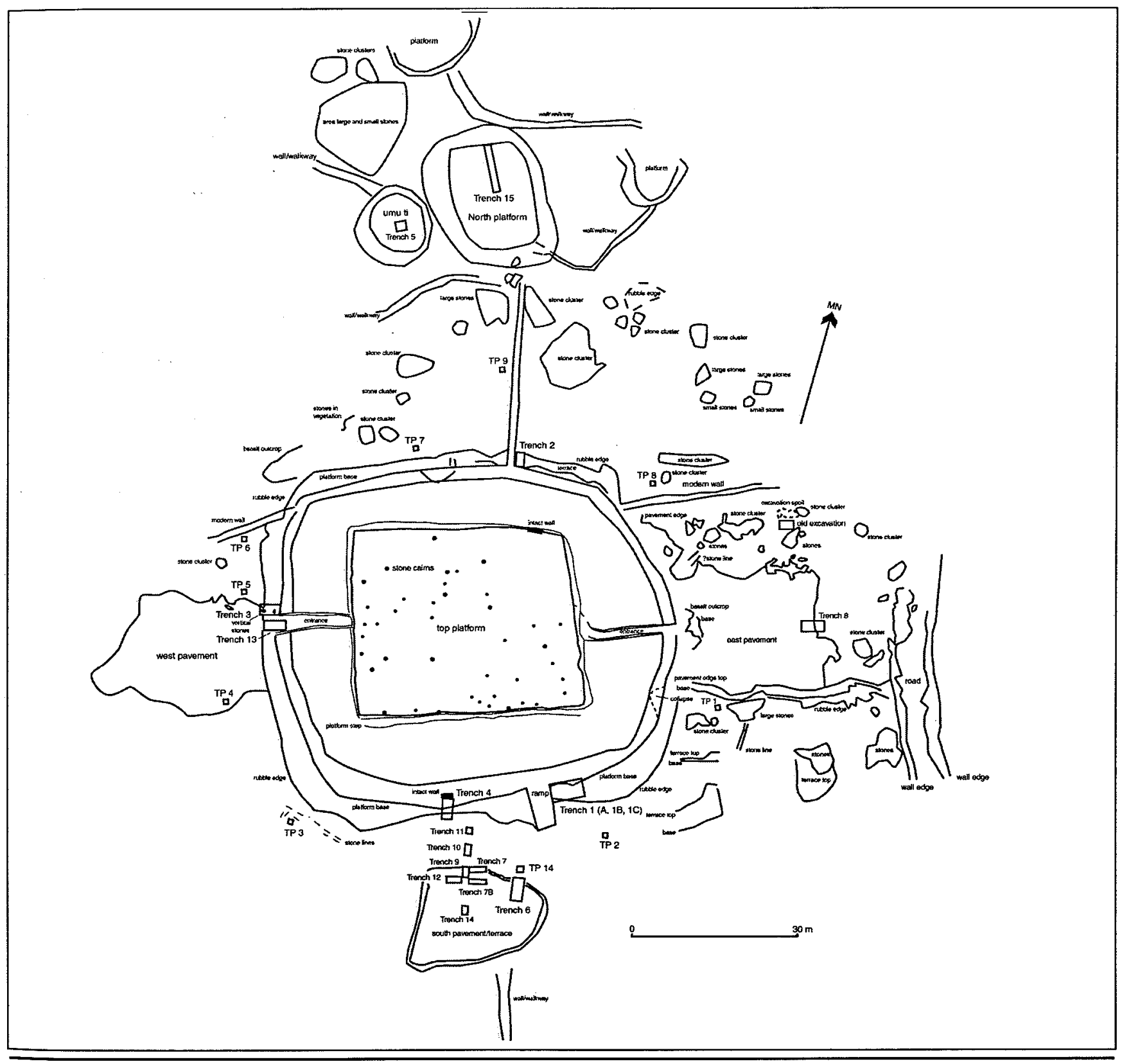

Figure 3a: Pulemelei mound and surrounding features. 

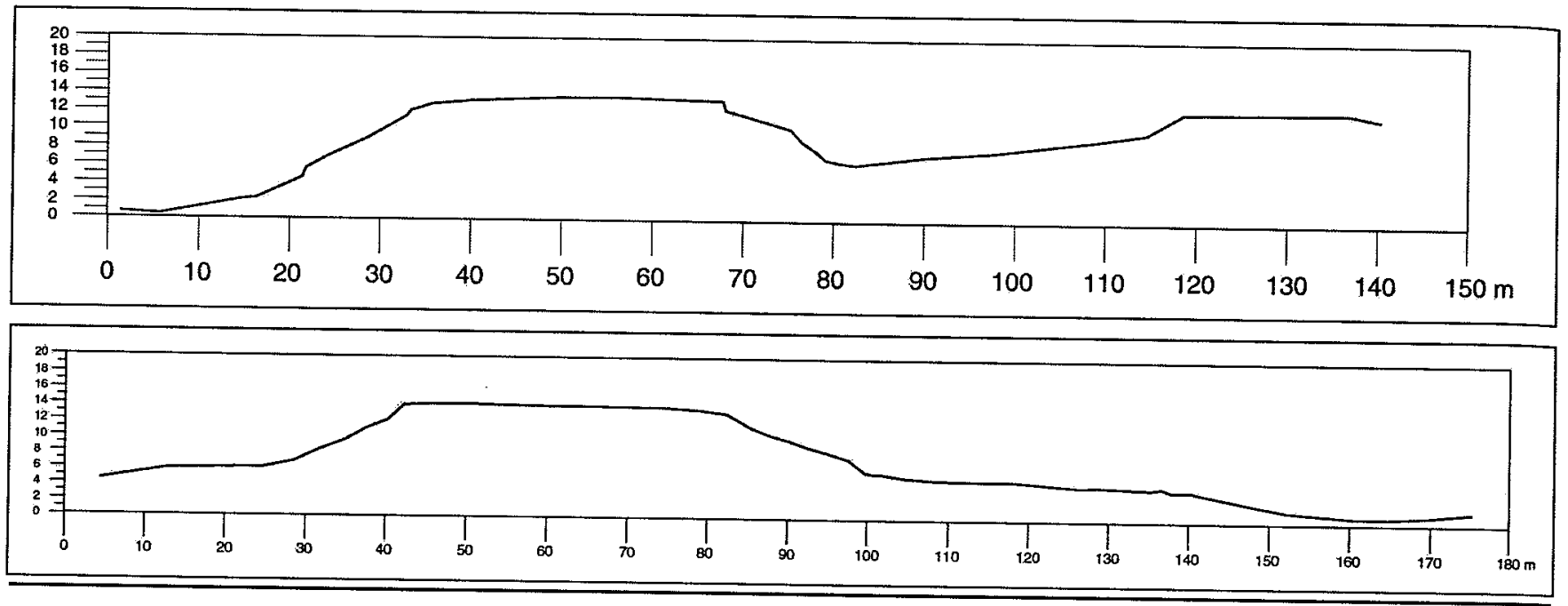

Figure 3b: North-South Section of Pulemelei and North mound; 3c: East-West Section of Pulemelei and East platform.

amount of stone collapse as a result of tree fall. Photos of the mound taken between 1965 and 2002 (in addition to photographs of the mound published by Green and Davidson (1969a), plus additional slides and photographs provided by Roger Neich, Peter Bellwood and Arne Skjølsvold) show that some parts of the mound have experienced substantial deterioration, particularly platform corners and wall sections of the base platform.

\section{Description of the Pulemelei mound}

The Pulemelei mound consists of a lower base platform on which was built at least two smaller platforms. Of the two smaller platforms the main structure is the top platform. Overall, the prominence of the base platform and top platform give the mound a stepped or two-tiered profile. Detailed mapping of the Pulemelei mound suggests it was constructed, however, in three distinct steps (Figure 4). The first step was the construction of the base platform with a level surface, and a higher wall on the south side than on the north side, due to the prevailing ground slope. A second step was then placed on the surface of the base platform, on top of which the third and final top platform was constructed. The base platform of the Pulemelei mound is $65 \mathrm{~m}$ along the east-west axis and $60 \mathrm{~m}$ along the north-south axis. The smaller top platform is $41 \mathrm{~m}$ along the east-west axis and 32 $m$ along the north-south axis. The entire mound was made from natural volcanic stones that are locally abundant, and no worked stones were identified in the mound.

The stone rubble along the edges of the mound is extensive, but in some areas where ramps or supporting walls were constructed the original walls of the mound have been preserved. The foundation of the base platform was outlined by placing a line of tabular basalt slabs upright in a shallow trench dug into the ground surface (Figure 5). The rectangular foundation outline was then filled by stacking the basalt slabs horizontally on top of the foundation stones until the base platform reached a height of 3-4 $\mathrm{m}$ on the south side. As a result of dry stone construction, the platform walls have sides slightly angled away from the vertical.

Above the base platform the stones slope inward, but it could not be determined if there had been one or more additional steps, or if there was a single sloping surface from the base platform to the base of the top platform. Along the south side of the mound just below the top platform there was evidence of a small step, but a corresponding feature was not seen on the north side. The top platform consists of a rectangular area paved with small water-rolled stones, and likely represents the final construction event. On the east

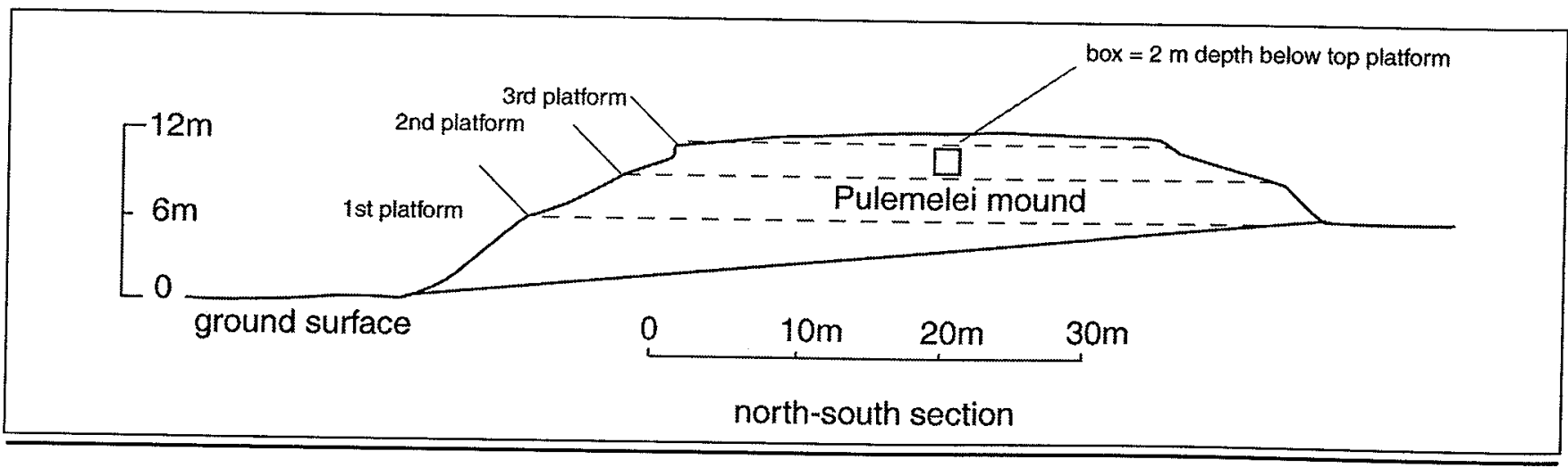

Figure 4. Detailed North-South Section of Pulemelei mound indicating three construction stages. 
and west side of the mound there are two sunken entranceways, which provide access to the top platform.

Extensive stone outfall caused by structure instability, tree growth and human activity is evident on all sides of the mound. The base platform originally had near vertical sides, but the second platform may have had slightly slanting sides. Due to subsequent wall collapse the sides of the base platform now appear to be steeply sloped. There has been relatively recent removal of stone from the mound to build fences on the east and northwest side of the structure (Figure 6). However, the entranceways on the east and west side of the mound, and the ramp on the south side, were probably constructed after the base platform was built, and indicate alteration of the Pulemelei mound in the past.

\section{Other structures in the vicinity of Pulemelei mound}

About $50 \mathrm{~m}$ to the north of the Pulemelei mound, and connected to it by a wall or raised walkway, is a smaller mound, we have called the 'North mound' (Figure 3a). The North mound is orientated north-south and has a base that is ca. $30 \mathrm{~m}$ long and $24 \mathrm{~m}$ wide. The top of the mound is ca. $20 \mathrm{~m}$ by $12 \mathrm{~m}$, and the mound surface is uneven and appeared unpaved. During excavation, small water-rolled

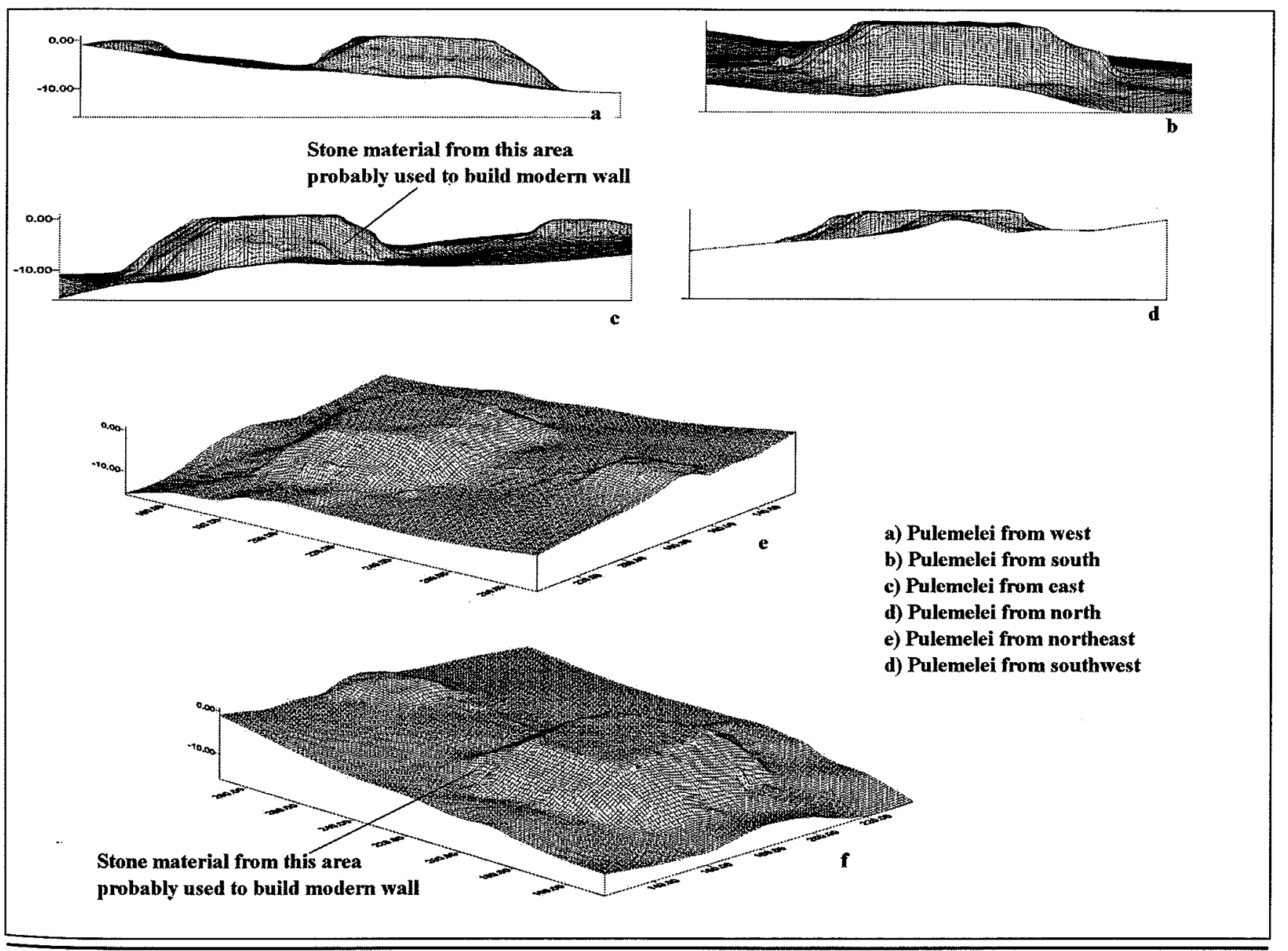

Figure 5. The foundation structure and original wall of first platform on the South side (Photo Paul Wallin)

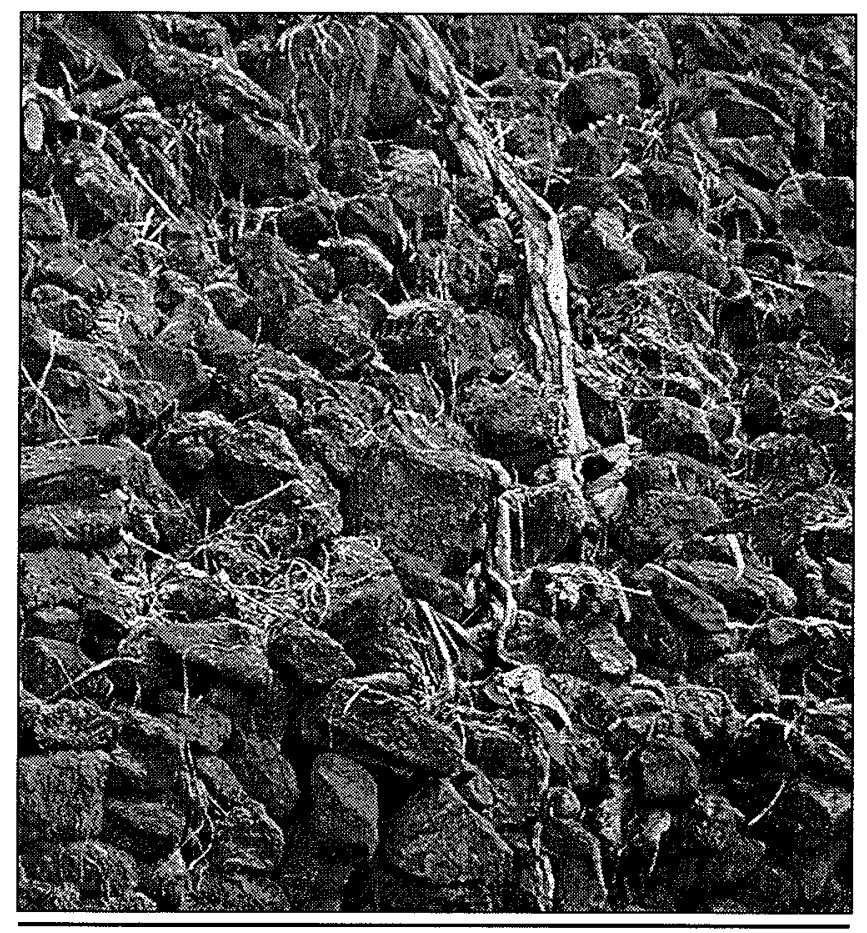


stones were found close to the mound surface. Due to tree root growth and collapse the paved surface of the North mound has been extensively disturbed. This has not occurred to the same degree on the Pulemelei mound due to more frequent vegetation clearance of the top platform, and the greater height and distance of the mound from surrounding vegetation. On the south side the North mound is ca. 2-3 m high and on the north side it is ca. $0.5 \mathrm{~m}$ high. The height difference is due to the slope of the ground surface, which slopes down toward the south. There are several pits on top of the North mound that are probably caused by tree collapse. Just west of the mound there is a raised rim oven with an exterior diameter of ca. 12-13 m (Figure 3a).

There are an additional 60 features around the Pulemelei mound that have been mapped and described. These features consist mainly of stone heaps, stone walls, large boulders and small platforms (Figure 3a). One of the stone heaps ( $F$ 12) was excavated in the 1960's (Scott 1969:82) and the trench could still be seen in 2004, and another stone heap ( $F$ 40) was excavated by us. The stone heaps were thought in the 1960 s to mark graves, but no human remains or cultural material were found in excavations below the stone piles, and they most likely represent clearance of surface stones.

The east entrance to the Pulemelei mound is located in an area of level bedrock, with a pavement of smaller stones continuing $25 \mathrm{~m}$ eastward. The east pavement has an asymmetric edge, and with its concave sides somewhat resembles a star mound platform. However, stone scavenging for plantation fences may have altered the pavement shape. About $15 \mathrm{~m}$ to the east of this pavement is a walled road (fua $i$ ala). On Jackmond's survey map the walled road continues upslope several hundred meters to the north, where his survey ended. Toward the northeast corner of the Pulemelei mound a modern stone fence connects to the mound, with another modern fence at the northwest corner, which continues westward some $60 \mathrm{~m}$. Stones from the mound and nearby prehistoric structures have probably been used to build this fence.

The west entrance to the Pulemelei mound also has an irregularly shaped pavement, but there was insufficient time to fully clear and map it. At the southwest corner of the Pulemelei mound there is a wall or raised walkway, which continues some $60 \mathrm{~m}$ to the west. On the north side of Pulemelei is a wall/raised walkway ca. $1 \mathrm{~m}$ wide and $0.5 \mathrm{~m}$ high, which connects the base platform of Pulemelei with the North mound. This north wall/walkway is joined to another walkway that continues to the west side of the North mound for about $30 \mathrm{~m}$. Midway between the North mound and the Pulemelei mound, and a few metres to the east of the connecting wall, is another pile of stones about $7-8 \mathrm{~m}$ in diameter. Near the end of the north wall/walkway is a cluster of large basalt boulders. Similar boulders are found along the north edge of the east pavement near the entrance to the Pulemelei mound. According to the Savai'i-based geologist, Warren Joplin, these large boulders have likely been moved from the riverbed. Such stones have probably been placed intentionally, and might have special significance. To the south of the Pulemelei mound is another pavement area which was identified as a house platform by Scott $(1969: 80)$.

\section{Excavations}

Nine test pits, (each $1 \mathrm{~m}^{2}$ ) were initially excavated around the Pulemelei mound and the North mound in 2002. One test pit close to the Pulemelei mound had a buried earth oven, and single ceramic sherds were found in two test pits, indicating early human activity in the area (Wallin et al. 2002). A total of fourteen test pits and sixteen trenches have been excavated, with a total excavation area of $112 \mathrm{~m}^{2}$ (Figure 3a).

Excavation showed that the thickness of the soil deposit varied around the Pulemelei mound, with outcrops of surface bedrock at the east entrance and to the northeast of the mound. At the west entrance the soil depth was over 1 $\mathrm{m}$, but in general the soil around the Pulemelei mound was ca. $60 \mathrm{~cm}$ in depth. A natural volcanic outcrop to the south of the mound has probably experienced some levelling of the top soil and been used in the past as a house platform, although all of the postholes mapped by Scott (1969) could not be identified in our investigations.

There is a simple sediment stratigraphy around the mound (Figure 7). The surface layer was a brown-yellowish humus soil mixed with silty-clayish loam $5-10 \mathrm{~cm}$ thick. Under this was a dark brown-to-yellow brown silty-clayey loam, with some rounded water-rolled and natural volcanic stones. This layer varied in thickness from 20 to $30 \mathrm{~cm}$ and contained scattered charcoal, which was found in almost all excavations. Below this was a dark yellow-brown siltyclayey with natural stones. Near the bedrock the sediment contained more clay. The bedrock was generally found at ca. $60 \mathrm{~cm}$ below ground surface.

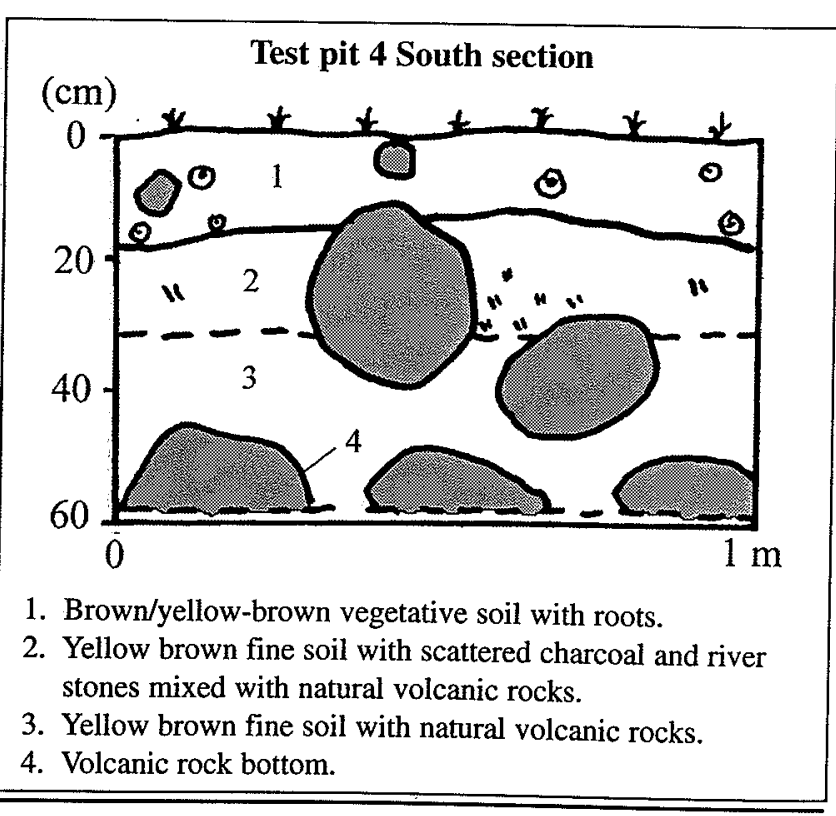

Figure 7. Typical stratigraphy in the area (TP 4). 


\section{Excavation at Pulemelei mound}

To investigate the construction of the Pulemelei mound one test pit and six trenches were excavated next to the mound walls at various places around the base platform (TP 1, Trench 1, 2, 3, 4, 13, 16) (Figure 3 a). The excavation trenches revealed the foundation slabs and dry stone wall of the base platform on the south, west and north side of the mound (Figure 5). The foundation stones of tabular basalt were found in Trench 1,2, and 13, and they varied in size ca. $70-100 \mathrm{~cm}$ in greatest length. On the east side of the mound, the volcanic outcrop was used as the wall foundation. One earth oven and scattered charcoal occurred at the foundation level, and two earth ovens were recorded
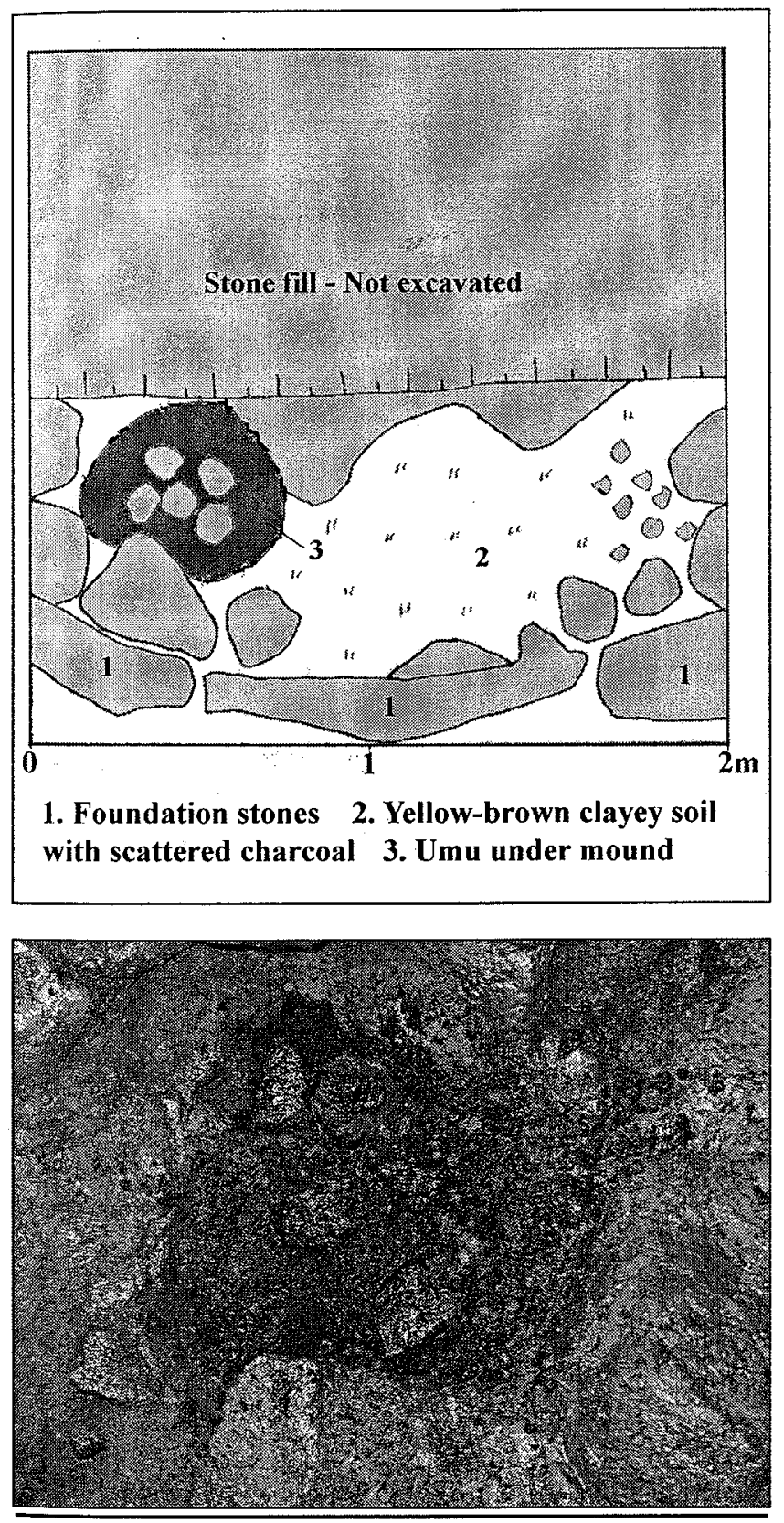

Figure 8. a: Plan of hearth under the mound and foundation stones (Trench 13);

b: Photo of the hearth. (Photo Helene Martinsson-Wallin) at a depth below the foundation stones, but outside the mound perimeter. An earth oven was also identified under the base platform in Trench 13 (Figure $8 \mathrm{a}, \mathrm{b}$ ).

Test pit 1 and Trench 1 excavated at the monument foundation level close to the south side of the base platform, uncovered an earth oven and some scattered charcoal. The earth oven is dated by sample (ANU-11891) and scattered charcoal by sample (Wk-13864) (Table 1). A charcoal concentration recovered close to the monument foundation level on the west side in Trench 2 is dated by sample (Wk-13865) (Table 1). An earth oven found in Trench 1 on the south side ca. $35 \mathrm{~cm}$ below the foundation level is dated by sample (Beta-172928) (Table 1), and charcoal samples from two earth ovens on the west side of the mound in Trench 3 and 13, also stratigraphically below the monument foundation level, and just outside and under the mound, are dated by two samples (Wk-13869) and (Wk-16640), respectively (Table 1 ). Trench 4 , excavated on the south side of the mound, did not penetrate to the monument foundation stones due to possibility of wall collapse.

Trench 16 was excavated to investigate the construction of the top platform. The stratigraphic sequence disclosed a top layer ca. $10-15 \mathrm{~cm}$ thick of small water-smoothed stones ('ili'ili), with larger stones and a sparse and discontinuous deposit of silty-clay to a depth of ca. $60-80 \mathrm{~cm}$. At this depth the water-smoothed stones became more prevalent again and at ca. $1.0 \mathrm{~m}$ larger stones and silty-clay were again recorded. When clearing the mound of vegetation the roots of several large trees were removed from the top platform. In doing so, a charcoal concentration was found at $60 \mathrm{~cm}$ below the top platform. The sample (ANU 11890) (Table 1) was sandwiched between two stones and did not appear to be fragmented charcoal that had infiltrated from the platform surface (Figure 9).

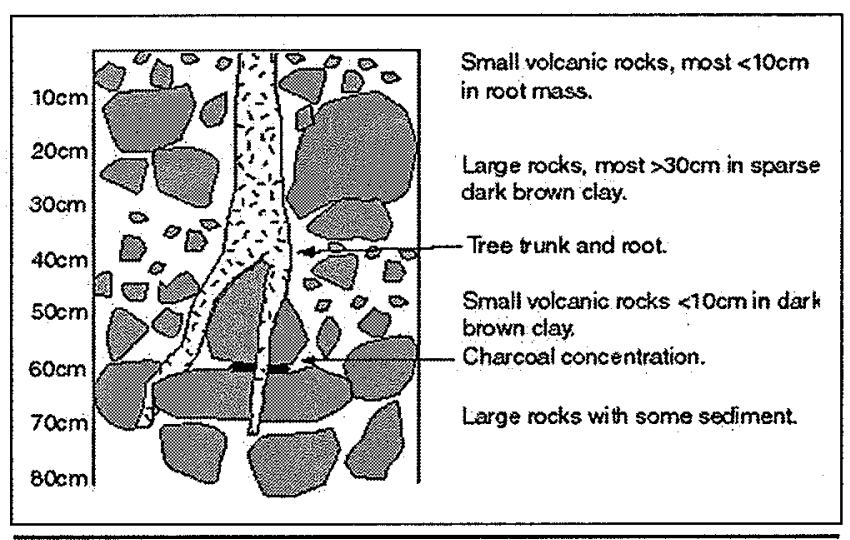

Figure 9. Section of top platform with tree stump and charcoal.

\section{Excavation of the Umu ti, and the North mound}

Jackmond's survey map showed a large raised-rim oven to the west of the North mound. Trench 5 was opened to study the structure, which confirmed it was a large earth oven with a size and morphology consistent with an $u m u$ ti oven (Figure 10). The Trench 5 excavation was $2 \times 2 \mathrm{~m}$, and was 


\begin{tabular}{|c|c|c|c|c|c|}
\hline SITE & LAB. NO. & AGE B.P. & AGE (1 SIGMA) & AGE (2 SIGMA) & FIND CONTEXT \\
\hline SS-Le-1 & Wk-13866 & $372 \pm 43$ & $\mathrm{AD} 1496-1521,1536-1626$ & AD 1462-1637 & Pulemelei, Umuti, Trench 5 \\
\hline SS-Le-1 & ANU-11890 & $310 \pm 90$ & $\mathrm{AD} 1495-1672,1743-1797$ & $\begin{array}{l}\text { AD 1449-1712, 1718-1813, } \\
1836-1951\end{array}$ & Pulemelei mound, top platform \\
\hline SS-Le-1 & Wk-13867 & $454 \pm 46$ & $\mathrm{AD} 1437-1500,1597-1611$ & $\mathrm{AD} 1418-1514,1542-1624$ & Pulemelei, S terrass/platform, Trench 6 \\
\hline SS-Le-1 & Wk-15503 & $657 \pm 34$ & AD 1313-1358, 1380-1395 & AD 1298-1401 & Pulemelei, Under N-Mound, Trench 15 \\
\hline SS-Le-1 & Beta-177607 & $680 \pm 80$ & AD 1294-1392 & AD $1229-1250,1260-1434$ & $\begin{array}{l}\text { Pulemelei, N-side c. }-20 \mathrm{~cm}, \text { Scattered in } \\
\text { Test Pit } 6\end{array}$ \\
\hline SS-Le-1 & Wk-13865 & $754 \pm 59$ & $\begin{array}{l}\mathrm{AD} 1233-1245,1264-1316 \\
\quad 1355-1382\end{array}$ & AD 1219-1391 & Pulemelei, Charcoal cons. N-side, Trench 2 \\
\hline SS-Le-1 & ANU-11891 & $780 \pm 120$ & $\mathrm{AD} 1184-1324,1344-1389$ & AD 1042-1092, 1099-1419 & Pulemelei, Umu at E-side, Test Pit 1 \\
\hline SS-Le-1 & Beta-172927 & $850 \pm 50$ & AD $1190-1273$ & AD 1053-1072, 1149-1291 & $\begin{array}{l}\text { Pulemelei, Charcoal conc. SW side, } \\
\text { Test Pit } 3\end{array}$ \\
\hline SS-Le-1 & Wk-13864 & $900 \pm 43$ & $\mathrm{AD} 1054-1060,1150-1228$ & $\mathrm{AD} 1046-1085,1110-1272$ & $\begin{array}{l}\text { Pulemelei, Charcoal scatter S-side, } \\
\text { Trench 1B }\end{array}$ \\
\hline SS-Le-1 & Wk-16642 & $955 \pm 44$ & $\begin{array}{l}\text { AD 1045-1086, 1108-1121, } \\
1128-1182\end{array}$ & AD 1033-1211 & Pulemelei, umu at S-side, Trench 10 \\
\hline SS-Le-PT & Wk-15504 & $992 \pm 34$ & $\mathrm{AD} 1036-1052,1076-1148$ & $\mathrm{AD} 1023-1162,1170-1175$ & $\mathrm{~Pa}$ Tonga, Letolo plantation Original surface \\
\hline SS-Le-1 & Wk-15502 & $1134 \pm 37$ & $\begin{array}{l}\text { AD 898-921, 944-994, } \\
1009-1011\end{array}$ & AD $891-1021$ & Pulemelei, scattered W-entrance, Trench 13 \\
\hline SS-Le-1 & Wk-16640 & $1135 \pm 34$ & $\mathrm{AD} 898-920,945-994$ & AD 894-1018 & $\begin{array}{l}\text { Pulemelei, Umu under Pulemelei mound, } \\
\text { Trench } 13\end{array}$ \\
\hline SS-Le-1 & Wk-13869 & $1157 \pm 44$ & AD 895-927, 934-987 & $\mathrm{AD} 783-788,814-843,860-1022$ & Pulemelei, Umu, W-side, Trench 3 \\
\hline SS-Le-1 & Beta- 172928 & $1250 \pm 100$ & $\mathrm{AD} 709-747,766-900,918-961$ & AD 659-1016 & Pulemelei, Umu at S-side, Trench 1 \\
\hline SS-Le-1 & Wk-13868 & $1993 \pm 55$ & AD $1-129$ & BC 51-227 AD & Pulemelei, Umu at plain ware site, Trench 7 \\
\hline SS-Le-1 & Wk-15501 & $2058 \pm 38$ & $\mathrm{BC} 45-32 \mathrm{AD}, \mathrm{AD} 36-52$ & $\mathrm{BC} 156-138, \mathrm{BC} 113-82 \mathrm{AD}$ & Pulemelei, Umu at plain ware site, Trench 9 \\
\hline
\end{tabular}

Table 1. Radiocarbon dated samples from the excavations at Pulemelei site. All samples are charcoal.

placed inside the rim of the oven. When the oven was cleared of vegetation the outer rim edge could be traced. The size of the oven was ca. $12 \mathrm{~m}$ in diameter and up to $1.5 \mathrm{~m}$ deep. The stones used in the oven varied in size between 20 $\mathrm{cm}$ and $60 \mathrm{~cm}$ in greatest length. Burnt vegetation was found among the oven stones, with a particularly concentrated deposit of large amounts of charcoal at the oven base, which was sloping bedrock. A charcoal sample from this deposit at the bottom of the umu has been dated (Wk 13866) (Table 1). The umu oven stones were blocky and quite large, and some had been weakened by exposure to high temperatures, and broke during removal. At the base of the umu the oven temperature had been high enough to oxidize the iron in the basalt stones, which were orange-red in colour. The large $u m u$ is interpreted as having been used for cooking the root of the $t \bar{i}$ plant (Cordyline fruticosa). The high temperature and prolonged cooking period required for $t^{-}$roots necessitated a large-sized oven and significant amounts of combustible fuel (Carson 2002:362). Based on ethnographic evidence the $t \bar{l}$ plant was cooked at high temperature in order to be caramelized, and through this metamorphosis it may have contributed to ritual ceremonies (Carson 2002:347).

The North mound beside the umu $t i$ was investigated with an excavation called Trench 15 that was $8 \times 1 \mathrm{~m}$ in length (Figure 11), and located from near the middle of the north edge of the mound toward the centre of the mound. The excavation showed that the North mound had once been paved with small, rounded stones, as is typical of many Samoan house platforms today, but vegetation growth and tree fall had dispersed much of the pebble surface. The North mound had a central core of large and small stones in silty-clay, while the outside mound edges were entirely of large rock. At the base of the mound there was a thick deposit of charcoal on the volcanic outcrop base. A sample from the base of the mound has been dated (Wk-15503) (Table 1). A basalt adze of Type X, and an adze flake were found in the silty-clay between stones, and had evidently fallen between platform stones in the past.

\section{Excavation of the South 'house' pavement}

The surface of the south terrace with a stone pavement (Figure 12) was paved with irregular volcanic rocks. Circular depressions on the stone pavement were identified as postholes by Scott (1969: 80), but only one possible posthole was verified during our excavation. Excavation of Trench 6, 7, 7b, 9, 12, 14 (Figure 3a) showed that beneath dark brown topsoil ca. $5 \mathrm{~cm}$ thick, there were a pavement 


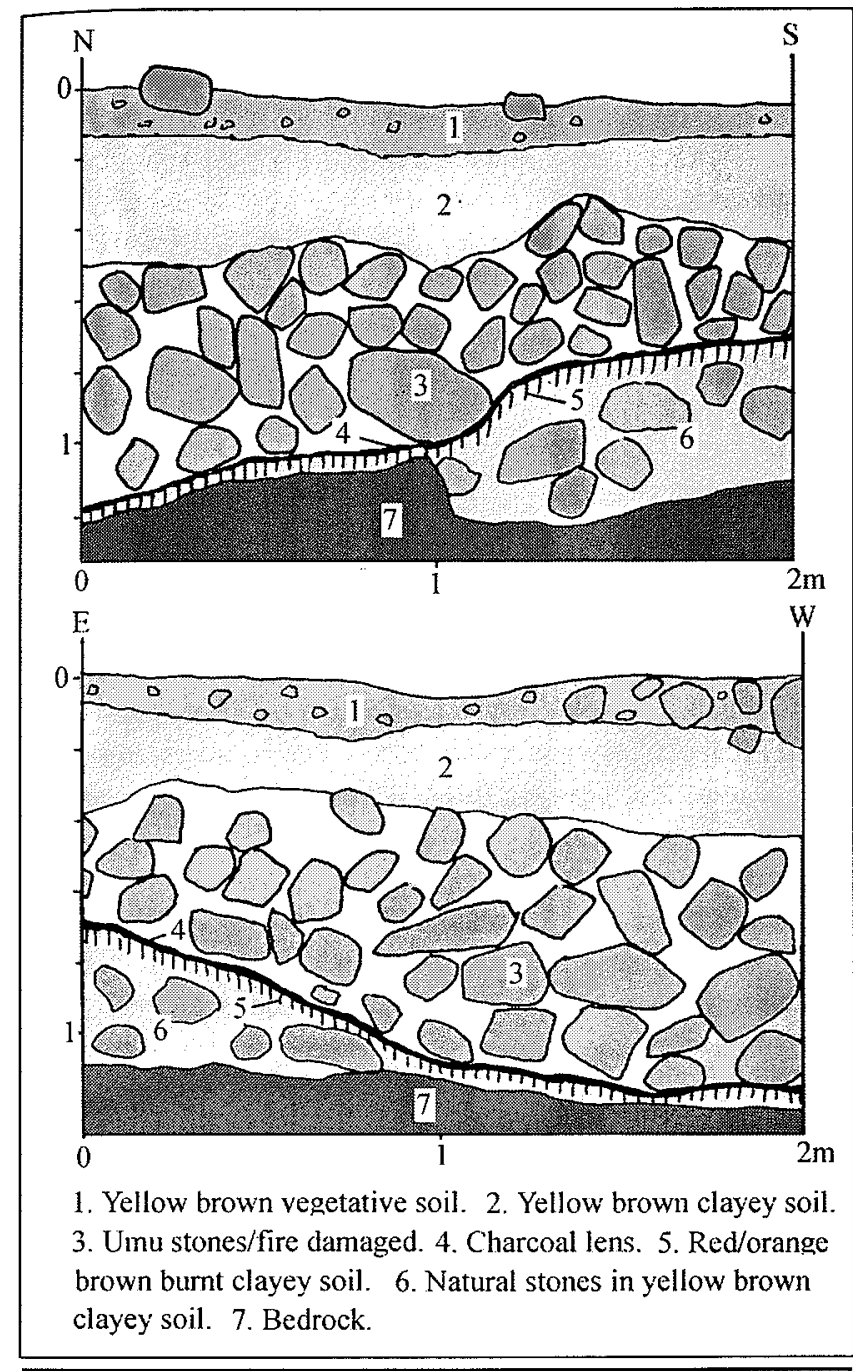

Figure 10. North-South (top) and East-West (bottom) sections of part of umu $t \bar{i}$ in trench 5.

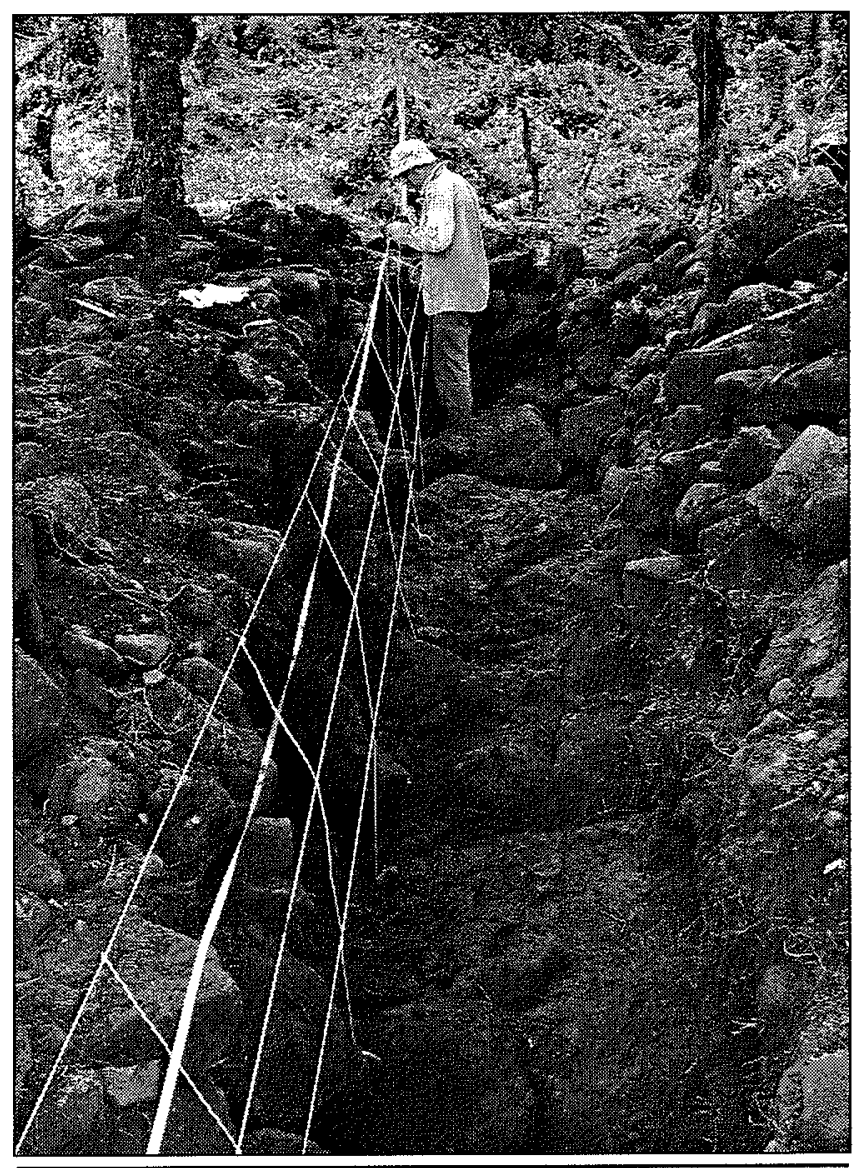

Figure 11. North-South section of North mound. (Photo Helene Martinsson-Wallin)

ca. $20 \mathrm{~cm}$ thick consisting of two stone layers and containing stones ca. $10-15 \mathrm{~cm}$ in greatest length. Among the pavement stones were some water-smoothed pebbles $5-10 \mathrm{~cm}$ in size, which are typically used for paving house floors today. In Trench 7 , the edge of a probable house foundation was found. The foundation edge consisted of eight stones that had been vertically placed in an east-west direction near the southern margin of the pavement (Figure 3a). A 'thick' ceramic sherd, fire-cracked stones mixed with charcoal and some water smoothed pebbles, as well as a few stone flakes were associated with this pavement. In Trench 9, a vertical slab and hole is interpreted as a posthole support. A charcoal concentration in the west-central part of Trench 6 has been dated (Wk13867) (Table 1).

Figure 12. Platform south of Pulemelei with house pavement and earlier settlement activities. (Photo Helene Martinsson-Wallin) 